\title{
CHARACTERISTICS OF ADOLESCENTS' ACTIVE LIFESTYLE IN THE CITY OF LJUBLJANA
}

\author{
Marta $\mathrm{BON}^{1}$ \\ ${ }^{1}$ University of Ljubljana, Faculty of Sports, Slovenia \\ Corresponding author: \\ Marta BON, Ph.D. \\ University of Ljubljana, Faculty of Sports, Gortanova 22, Ljubljana, Slovenia \\ phone: +38651670581 \\ E-mail: marta.bon@fsp.uni-lj.si
}

\section{ABSTRACT}

Purpose: The aim of our study was to analyse the characteristics of the adolescents' active lifestyle and their relationship to some environmental correlates in the city of Ljubljana.

Methods: The characteristics of active lifestyle on the sample of 269 students of Secondary School of Nursing Ljubljana (206 females, 63 males), aged 16-18 years) via an online questionnaire were evaluated. Descriptive statistics and Fisher's exact test were used (at $p<0.05-5 \%$. level). In the second part, we used half-structured interviews with former students of the same school (no. 6); to evaluate their attitude to physical education lessons, their general active lifestyle and their evaluation of the environmental correlates: physical (facilities, equipment), social (social support and social norms) or institutional (policies).

Results: Results show that the majority of students (44.96\%) was physically active at least two to three times per week. The students partly agree (3.7/5) that sports activities play an essential role in their general lifestyle. Furthermore, they care about leading a healthy lifestyle (3.7/5) and eating healthy food (3.7/5). Students evaluated both physical factors (at the municipality level $76.15 \%$, at the state level $71.49 \%$ ), and social (parents) support as appropriate. The former students believe that physical environmental factors around their school (facilities, equipment) are optimal, but they regret that they did not use them enough; neither during PE lessons nor in their leisure time.

Conclusion: Based on our results, we propose better cooperation between all the included factors, which can result in the improvement of adolescents' active lifestyle.

Keywords: lifestyle, sport, adolescents, Ljubljana, environmental correlates. 


\section{ZNAČILNOSTI AKTIVNEGA ŽIVLJENJSKEGA SLOGA MLADOSTNIKOV V MESTNI OBČINI LJUBLJANA}

\section{IZVLEČEK}

Namen: Namen naše raziskave je bil analizirati značilnosti aktivnega življenjskega sloga mladostnikov in odnos do nekaterih okolijskih dejavnikov v mestu Ljubljana.

Metode: S pomočjo spletnega vprašalnika so bile ovrednotene značilnosti aktivnega življenjskega sloga na vzorcu 269 dijakov Srednje zdravstvene šole Ljubljana (206 žensk, 63 moških, starih 16-18 let). Uporabljeni so bili opisni statistični podatki in Fisherjev natančni test (pri $p<0,05$ - 5\% stopnja). V drugem delu so bili izvedeni polstrukturirani intervjuji z nekdanjimi dijaki te šole (6), s katerimi so bila opredeljena njihova stališča do aktivnega življenjskega sloga sploh ter posebej odnosa do športne vzgoje in je bil ovrednoten njihov odnos do okolijskih dejavnikov: fizičnih (objekti, pogoji, oprema), socialnih (socialna podpora in socialne norme) ali institucionalnih (predvsem lokalne politike).

Rezultati: Rezultati kažejo, da je bila večina dijakov (44,96\%) vsaj dva do trikrat na teden telesno dejavnih. Dijaki se delno strinjajo (3.7/5), da imajo športne aktivnosti bistveno vlogo v njihovem življenjskem slogu. Poleg tega dijaki navajajo, da skrbijo za zdrav življenjski slog (3,7/5), uživajo zdravo hrano (3,7/5). Dijaki so okolijske (fizične) dejavnike ocenili kot ustrezne (na ravni občine 76,15\%, na državni ravni 71,49\%) in socialno oporo (starši), kot primerno. Nekdanji dijaki tudi ocenjujejo fizične oz. prostorske možnosti v okolici šole kot optimalne, vendar obžalujejo, da jih niso uporabljali $v$ večji meri tako med poukom, kot v prostem času.

Zaključek: Na podlagi rezultatov predlagamo boljše sodelovanje med vsemi navedenimi dejavniki, kar lahko pripomore k izboljšanju aktivnega življenjskega sloga mladostnikov.

Ključne besede: življenjski slog, šport, mladostniki, Ljubljana, dejavniki okolja. 


\section{INTRODUCTION}

Physical activity (PA) is one of the key health determinants in life (Fletcher et al., 1996; Gunter, Almstedt, \& Janz, 2012; Janssen \& Leblanc, 2010). It is one of the sources of total energy expenditure, which incorporates active energy expenditure, metabolism in resting state, the thermal effects of food digestion and body growth in children and adolescents (Armstrong \& Welsman, 2006). The existing evidence shows that PA has positive effects on psychosocial health, and the functional capacity and wellbeing of people (Brettschneider \& Roland, 2004; Lima et al., 2017; Powell \& Pratt, 1996)Inc. Background: The current study evaluated the reciprocal longitudinal relationship between physical activity (PA, whereas physical inactivity increases health risks (Hallal et al., 2012). Despite these established benefits, a substantial proportion of children are not meeting (Aubert et al., 2018) PA recommendations of 60 min moderate to vigorous PA (MVPA) daily (World Health Organization, 2010). Moreover, participation declines during the transition from childhood to adolescence (Dalene et al., 2018; Farooq et al., 2018; Kimm et al., 2002), with PA increasingly replaced with sedentary activities (Brodersen, Steptoe, Boniface, \& Wardle, 2007; Volmut, Pišot, \& Šimunič, 2013)ethnicity and socioeconomic status (SES. Given that young people spend approximately half of their waking day at school, schools represent an essential setting for promoting physical activity and reducing sedentary behaviours (Morton, Atkin, Corder, Suhrcke, \& Van Sluijs, 2016).

PA interventions tend to focus on increasing knowledge through health education and implementing curriculum to increase the number of time students are engaged in PA (Morton et al., 2016) during the school day. Generally speaking, these interventions have not been successful for adolescent populations (Dobbins, Husson, DeCorby, \& LaRocca, 2013). A general criticism directed at many school-based interventions is the lack of attention paid to the role of the wider environment (Doak, Visscher, Renders, $\&$ Seidell, 2006). PA behaviour is not driven only by consideration of knowledge, attitudes and beliefs; but can also be automatically enriched by environmental stimuli (Dunton, Cousineau, \& Reynolds, 2010; Marteau, Hollands, \& Fletcher, 2012). These factors may be physical (facilities, equipment), social (social support and social norms) or institutional (policies) (Morton et al., 2016).

Sport is an increasingly important human activity and part of the general culture, which considerably enriches the life of an individual and is a significant element in quality of life.

In the literature review of the correlates of sports activity, some differences emerge. First, the empirical analyses use different measures of sport participation. A large number of studies analyse whether or not individuals perform sports activities (e.g. Bauman et al., 2012). The second set of studies also analyses the frequency of participation or duration of the activity and expenditures (e.g., Farooq et al., 2018, Bon, Lavrič, Gradišar-Saifet, \& Kambic, 2019).

One of the environmental correlates are state and city policies. Sport in the Municipality of Ljubljana is based on the Sports Act (2017) and other municipality regulations. 
Sports Policy in the City of Ljubljana is one of the health-enhancing acts of the City Council of Ljubljana (CCL), which is the supreme body that determines all matters within the framework of the rights and obligations of the City of Ljubljana. The most important strategic goals in the document titled "Strategy for the Development of Sport in the City of Ljubljana 2008-2012” (Bon, Kolenc, Peršolja, \& Tomc, 2008) were mostly connected with sport facilities: to improve and increase the number of outdoor facilities (outdoor fitness, recreational areas near the Sava river, skate parks, etc.) and to build new indoor facilities such as the Sports Centre Stožice, Gymnastic Centre Ljubljana, Kolezija Swimming Pool, etc. (Bon et al., 2008).

Our study aimed to examine some characteristics of adolescents' lifestyle and evaluate the perception of environmental correlates, especially all settings and conditions around the Secondary School of Nursing Ljubljana $(\mathrm{r}=2 \mathrm{~km})$.

\section{METHODS}

Our study combined qualitative and quantitative methods. In the first part, we analysed the data about lifestyle and conditions (Bon et al., 2019) obtained via e-survey (no. 269). The second part included structured interviews (no. 6) to evaluate the characteristics of physical education (PE) in school and school surroundings in the City of Ljubljana.

A total number of 269 adolescents (206 females), aged 16-18, students of the Secondary School of Nursing Ljubljana participated in the study. Each participant was informed about the purpose of the study and a written informed consent was obtained from all adolescents. The participation was anonymous, and participants were free to withdraw from the study at any time and for any reason.

All respondents' answers were rated on a 5-point Likert scale. Responses on the subscale ranged on a scale $1-5$, where one represents not satisfied or very unimportant and five very satisfied or very important. The validity of the used questionnaire (alpha 0.78 ) is sufficient. Apart from the descriptive statistics, Fisher's exact test was used (at $\mathrm{p}<0.05-5 \%$. level).

Data were collected on the " $1 \mathrm{ka}$ " platform (Faculty for Social Sciences, University of Ljubljana) and analysed in the program IBM SPSS 19 (SPSS Inc., Chicago, USA).

Additionally, in the qualitative part six semi-structured interviews were conducted with an aim to shed further light on the results with three female and three male students all finishing school within three years (born 1998 or younger). At the end an overview of sports facilities around the school $(2 \mathrm{~km})$ was made by analysing available documentation about sports facilities in the city of Ljubljana.

The transcription of the semi-structured interviews and data organization was followed by the descriptive encoding and the data validation process. The first validation phase was about the accuracy of the design/methods, and the second about the reliability of the procedures to produce consistent and dependable results. Finally, the data analysis stating the findings and research outcomes based on the research objectives 
were concluded. Our goal was to find a valid link between the analysed data and the research questions.

In the first part of the study, the invitation for voluntary participation was sent to all students of the Secondary School of Nursing Ljubljana of the year 2018/19, followed by life face-to-face or phone conversation to explain the purpose of the study. After a positive response from the students, participants completed an online survey on the " $1 \mathrm{ka}$ " platform. After a descriptive analysis of the answers from all students, the interview process was organized. It included six students of the Secondary School of Nursing ( 3 females, 3 males), aged 16-18, who have already finished the first two years of school. The individuals who agreed to participate in interviews, signed an informed consent after a detailed description of the purpose of the study and their participant's rights. The interviews lasted 30 to 40 minutes and were conducted by one person (first author).

All steps in the testing procedure were conducted in accordance with the ethical standards of a responsible local human experimentation committee and with the Helsinki Declaration as revised in 2013.

\section{RESULTS}

\section{Results of the Questionnaire}

The results of the questionnaire are presented in Table 1 . The students partly agree $(3.7 / 5)$ that sports activities play an important role in their lifestyle. Furthermore, they care about leading a healthy lifestyle (3.7/5) and eating healthy food (3.7/5).

More than half of adolescents occasionally (69.42\%) consume alcohol, and some of them even take drugs. Only $44.9 \%$ of the included students reaches the recommendations for PA of $150 \mathrm{~min}$ PA/week. 31 students (12.0\%) are physically active only once per week and $21(8.14 \%)$ even less than once per month. Results show that there is no significant difference between gender $(\mathrm{p}=0,159)$ and age $(\mathrm{p}=0.753)$ regarding PA. The majority of respondents $(84.40 \%)$ see the social and emotional support of their parents as appropriate, and the results are similar for those within the school $(69.26 \%)$. Most of them also perceive the environmental correlates - physical (conditions, facilities) and social support (parents, teachers) as appropriate (in municipality $76.15 \%$, at the state level 71.49\%). On average, they spend 123.6 EUR (from 6 to 1000 EUR) per month for sports activities. According to official data, students have many possibilities for indoor sports (in Ljubljana around 130,000m2) and outdoor sports (outdoor fitness, trim trails, and especially Golovec hill and Kodeljevo sports park), which create a near-optimal environment for an active lifestyle.

We asked them about social support (family, school). Out of all, 86.4\% announced that they have appropriate social support from parents, and $73.6 \%$ are happy with the support in school. 
ANNALES KINESIOLOGIAE ・ 10 • 2019 • 2

Marta BON: CHARACTERISTICS OF ADOLESCENTS' ACTIVE LIFESTYLE IN THE CITY OF LJUBLJANA, 87-98

\begin{tabular}{|c|c|c|c|c|c|c|c|c|c|c|c|c|c|}
\hline के & \multicolumn{2}{|c|}{ ઼ָ } & \multicolumn{2}{|c|}{$\begin{array}{l}\infty \\
\infty \\
0\end{array}$} & \multicolumn{2}{|c|}{$\begin{array}{l}\infty \\
0 \\
0\end{array}$} & \multicolumn{2}{|c|}{$\stackrel{\Xi}{m}$} & \multicolumn{2}{|c|}{$\stackrel{\simeq}{\leftrightarrows}$} & \multicolumn{2}{|c|}{$\begin{array}{l}\infty \\
\infty \\
0\end{array}$} & $\tilde{n}$ \\
\hline$\Sigma$ & \multicolumn{2}{|c|}{$\dot{r}$} & \multicolumn{2}{|c|}{$\vec{m}$} & \multicolumn{2}{|c|}{$\stackrel{\sim}{r}$} & \multicolumn{2}{|c|}{$\underset{\sim}{0}$} & \multicolumn{2}{|c|}{ } & \multicolumn{2}{|c|}{$\stackrel{ナ}{-}$} & 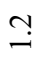 \\
\hline$\sum_{\infty}$ & $\vec{n}$ & $\begin{array}{l}\stackrel{0}{8} \\
8 \\
8 \\
8\end{array}$ & $\stackrel{\circ}{\text { ¿ }}$ & $\begin{array}{l}80 \\
8 \\
\dot{8} \\
8\end{array}$ & $\underset{\sim}{\sharp}$ & $\begin{array}{l}\stackrel{0}{8} \\
\dot{8} \\
\dot{8}\end{array}$ & $\stackrel{\stackrel{ }{\sim}}{\sim}$ & $\begin{array}{l}\stackrel{0}{0} \\
8 \\
0 \\
8\end{array}$ & $\stackrel{\overbrace{}}{\sim}$ & $\begin{array}{l}\stackrel{0}{8} \\
\dot{0} \\
8\end{array}$ & $\stackrel{\stackrel{\sim}{\sim}}{\sim}$ & $\begin{array}{l}\stackrel{0}{8} \\
\text { ᄋ } \\
\stackrel{8}{8}\end{array}$ & $\vec{J}$ \\
\hline 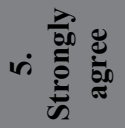 & $\Re$ & $\begin{array}{l}\stackrel{0}{0} \\
\stackrel{0}{0} \\
\stackrel{2}{0}\end{array}$ & \& & $\begin{array}{l}\text { ठें } \\
\text { กู } \\
\text { }\end{array}$ & 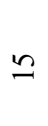 & $\frac{\stackrel{0}{i n}}{6}$ & ㄱ & $\begin{array}{l}\stackrel{\circ}{\Delta} \\
\stackrel{\sigma}{0}\end{array}$ & 으 & 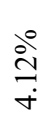 & in & $\begin{array}{l}\stackrel{0}{\hat{0}} \\
\stackrel{0}{i}\end{array}$ & - \\
\hline 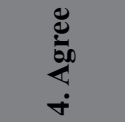 & ঃ & $\begin{array}{l}\dot{0} \\
\dot{0} \\
\ddot{n} \\
\text { n. }\end{array}$ & $\Xi$ & $\frac{\stackrel{0}{1}}{\dot{y}}$ & $\nabla$ & $\begin{array}{l}\stackrel{0}{0} \\
\text { ¿ें }\end{array}$ & $\widetilde{\sigma}$ & $\begin{array}{l}\text { ¿ें } \\
\text { ¿ें } \\
\text { ते }\end{array}$ & $\cong$ & $\frac{^{\circ}}{\sigma^{\circ}}$ & 0 & $\begin{array}{l}\stackrel{0}{\circ} \\
\stackrel{\infty}{+} \\
\stackrel{+}{+}\end{array}$ & $\sim$ \\
\hline 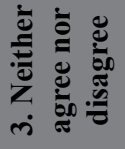 & $\stackrel{\wp}{f}$ & $\frac{\stackrel{\circ}{ }}{\grave{n}}$ & $\stackrel{\infty}{\sim}$ & $\frac{\partial^{\circ}}{\frac{1}{m}}$ & $\Xi$ & $\frac{\stackrel{0}{a}}{\stackrel{5}{\sigma}}$ & $\hat{n}$ & 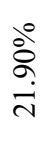 & $\stackrel{\infty}{-}$ & $\frac{\stackrel{\partial}{\partial}}{\stackrel{\gamma}{r}}$ & 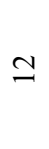 & $\begin{array}{l}\text { ठें } \\
\text { oे } \\
\dot{\nabla}\end{array}$ & 0 \\
\hline 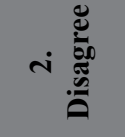 & $\hat{\sim}$ & $\begin{array}{l}\dot{b}_{0}^{\circ} \\
\frac{a}{0}\end{array}$ & $=$ & $\begin{array}{l}\stackrel{\circ}{+} \\
\stackrel{+}{+}\end{array}$ & 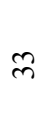 & $\begin{array}{l}\stackrel{0}{ } \\
\text { ñ } \\
\stackrel{2}{n}\end{array}$ & లి & $\begin{array}{l}\stackrel{0}{\infty} \\
\infty \\
\dot{\Xi}\end{array}$ & $\stackrel{+}{m}$ & 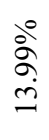 & $\hat{\sim}$ & $\begin{array}{l}\stackrel{0}{0} \\
ٍ \\
=\end{array}$ & $\tilde{\sim}$ \\
\hline 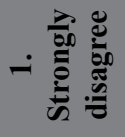 & ㄱ & $\frac{\stackrel{\circ}{\hat{a}}}{2}$ & 0 & $\begin{array}{l}\stackrel{\circ}{+} \\
\stackrel{+}{i}\end{array}$ & $\infty$ & $\begin{array}{l}\stackrel{0}{ } \\
\text { ஸे } \\
\text { ஸे }\end{array}$ & ホ & \begin{tabular}{l}
$\stackrel{0}{ }$ \\
$\infty$ \\
$n$ \\
\hdashline \\
$n$
\end{tabular} & $\stackrel{0}{0}$ & $\frac{\partial}{m}$ & ๙ & 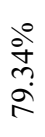 & 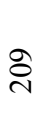 \\
\hline 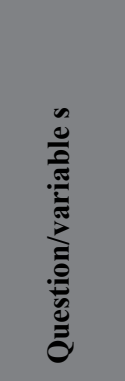 & 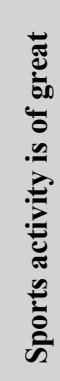 & & & & & & 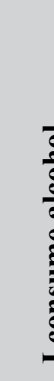 & & & & & & 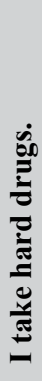 \\
\hline
\end{tabular}




\section{Qualitative Results}

An evaluation of the survey results clearly shows that there were different opinions about the degree to which (living/physical) environment affected PA level of adolescents of Ljubljana. Students are of the opinion that PE teachers could ask more from them during physical education lessons.

- Student W 1: "We never go to Golovec, a hill near the school, or to any facility around the school. We once used Kodeljevo sports park, only for a $2400 \mathrm{~m}$ run test. “

Students also agree that they were not motivated enough for sports activities, they tended to avoid sports activities and rest during PE lessons;

- Student W 2: "We were happy when our PE teacher allowed us to sit and talk... and we were gossiping .... I must admit that it was only in the first class when we had one old teacher."

It was also pointed out that especially the participation of female students in PE classes was additionally limited due to personal and hygiene reasons.

- Student W3: "I like sport, but I did not participate much in PE classes, because I really hated to sweat, I hate to be wet and to stink after a PE class... For all of us, the "sweating situation" was the biggest problem."

It is difficult to determine if these are excuses, or these hygiene reasons are a legitimate influencing factor, and it is necessary to find an organisational solution (bathrooms, showers, time-space for showering...). Student W3 also admitted: "From today's perspective, I am sorry that I wasn't more active during PE classes: But we really did not have time to take a shower afterwards."

Students also honestly admitted that they were trying to avoid PE classes to study for other tests and exams.

- Student W1: "Many of us were studying for a test (in one of the next periods) during our PE classes. “

- Student W2: "I'm really not quite sure what the main reason that girls didn't do much sport in PE classes was. It was a sort of combination of girls 'laziness, conditions (only half of the sports hall) and teachers' insufficient motivation, which all resulted in sport not having any real value in our school. "

It is evident that male students have an entirely different perception. They did not mention hygiene reasons (sweating) and showed ambition to be even more active (M1, M2, M3)

- Student M1: "I liked that we could suggest to our PE teacher what we wanted to do - mostly it was football ".

- Student M2: "Mostly we were in the school sports hall. Only once we were on Golovec Hill and once at the Kodeljevo stadium. I liked it very much, and I'm still sorry that we didn't use these possibilities more."

- Student M 3: "I would have liked our lessons to be more intensive and that we would have had PE every day." 
From these results, we can conclude that for female students the hygiene concern is a significant barrier to participating more in PE and leading a more active lifestyle, while male students would like to participate in more activities and dedicate more time to PE. Male students are aware of the wide range of possibilities in the school surroundings, and they would have liked to use those facilities around school more. Female students, on the other hand, are not so aware of these facilities and possibilities, their answers were mainly "I'm not quite sure", "I didn't care". It seems that during PA, their focus was more on body aesthetics and 'good looks'.

\section{Sports Facilities around the School in Connection with City Sports Policies}

Sports policy in the city is of vital importance, as the majority of sports facilities are in the domain of the City of Ljubljana. The basic goals in the field of sports in the City of Ljubljana are sustainability, accessibility, the competence of professional staff and fairness. More than $11 \%$ of the city budget is intended for sport, for the implementation of the sports strategy - to manage sports facilities, in one of the first priority.

Sports facilities and natural environment correlates, within $2 \mathrm{~km}$ radius around the school:

- Golovec Hill (250m-2,5km),

- Kodeljevo Park (football, tennis, swimming pool) - (200m),

- outdoor fitness (in front of the school) $(10 \mathrm{~m})$ and

- Ljubljana Caste hill (300m).

Those are physical factors which are of free of charge, available for all people. In this circle of $2 \mathrm{~km}$ there are, besides the sports hall at the Secondary School of Nursing Ljubljana, also: Sports Hall Kodeljevo, Sports Hall Poljane, facilities at the Faculty of Sport and some with private owners.

\section{DISCUSSION AND CONCLUSION}

Regular PA during adolescence provides numerous benefits; that why it is important to organize and implement the environmental correlates in the supportive way - to improve the level of adolescents' active lifestyle. In general, our results show insufficient level of sports activity, according to the recommendation of the World Health Organization (WHO), which states that youngsters, from 5 to 17 years of age, should engage in moderate to vigorous physical activity (MVPA) daily for at least $60 \mathrm{~min}$, and in vigorous physical activity (VPA) at least three times a week.

As in many countries all over the world, where there is an increasing academic and policy interest (e.g. Van Hecke et al., 2016; Farooq et al., 2018) in interventions aiming to promote young people's health by ensuring that the school environment supports healthy and active (sports) behaviours, we can see similar strategies also in Slovenia, particularly in Ljubljana, where the City of Ljubljana has more than 103 indoor and 83 
outdoor facilities, which can all be used to promote active lifestyle for adolescents. Regarding environmental correlates, the majority of our respondents perceive conditions in Ljubljana as appropriate. Our adolescents are aware that sport and physical education are an important part of their lifestyle, but it is evident that adolescents, as well as teachers of PE, are not motivated enough to make full use of the facilities available to them. Many factors influence the complex behaviour of adolescents PA (Bauman et al., 2012; Gustafson \& Rhodes 2006; Telama, Nupponen, \& Laakso, 2007). Support from peers, socio-economic status, parental education, school policies and environmental correlates emerged as potential determinants of PA (Ferreira et al., 2007). The results show that students, as well as teachers, lack a higher level of motivation for more dedicated work in active sports life. It seems that adolescents are not aware that being active is first and foremost their responsibility. The institutional environmental correlates (teachers, officials, sports policies) have to find a suitable model to makes adolescents more motivated and committed to leading an active lifestyle.

In general, sport communication strategies might play a prominent role in persuading potential participants of the benefits of sports activity and frequency for adolescents.

Identifying and understanding factors that can improve childhood and adolescent physical activity is necessary to design and implement effective interventions. Recent years have witnessed a growing interest in environmental factors that influence physical activity: physical (e.g. physical structures and facilities), social (e.g. support and norms) and institutional (e.g. school rules and policies). In addition to sports activities, one major contribution to childhood physical activity lies in free active play and unstructured physical activities taking place outdoors during their free time. This type of play provides numerous benefits in terms of cognitive, social and physical development (Van Hecke et al., 2016; Farooq et al., 2018; Dobbins et al., 2013; Bauman et al., 2012).

The adolescents in our study are of the opinion that physical environmental factors (facilities, equipment) are not used enough, but they are happy with social support and institutional (city, state) factors. Based on our results, we propose better cooperation between all the factors involved, which can improve the active lifestyle of adolescents.

The specifics of active lifestyle on one hand and connection with structured (school, sport clubs, etc.) and unstructured (outdoor) correlates on other, could be an interesting research topic for the future.

\section{REFERENCES}

Armstrong, N., \& Welsman, J. R. (2006). The Physical Activity Patterns of European Youth with Reference to Methods of Assessment. Sports Medicine, 36(12), 1067-1086. https://doi.org/10.2165/00007256-200636120-00005.

Aubert, S., Barnes, J., Abdeta, C., Abi Nader, P., Adeniyi, A., Aguilar-Farias, N., ... S. Tremblay, M. (2018). Global Matrix 3.0 Physical activity report card grades for chil- 
dren and youth: results and analysis from 49 countries. Journal of Physical Activity \& Health, 15(s2), S251-S273. https://doi.org/10.1123/jpah.2018-0472.

Bauman, A. E., Reis, R. S., Sallis, J. F., Wells, J. C., Loos, R. J. F., Martin, B. W., \& Group, L. P. A. S. W. (2012). Correlates of physical activity: why are some people physically active and others not? The Lancet, 380(9838), 258-271. https://doi.org/10.1016/ S0140-6736(12)60735-1.

Bon, M., Kolenc, M., Peršolja, B., \& Tomc, G. (2008). Primer izhodišč strateškega načrta na področju športa do leta 2012-Mestna občina Ljubljana [An example of starting points of a strategic plan for sport until 2012-the urban municipality of Ljubljana]. Šport: revija za teoretična in praktična vprašanja športa, 56(1/2), 8-13.

Bon, M., Lavrič, A., Gradišar-Saifet, K., \& Kambic, T. (2019). Telesna aktivnost dijakov Srednje zdravstvene šole Ljubljana [Physical activity of the students of the Secondary School of Nursing Ljubljana]. Šport: revija za teoretična in praktična vprašanja športa, 67(2-3), 156-160.

Brettschneider, W.-D., \& Naul, R. (2004). Study on young people's lifestyles and sedentariness and the role of sport in the context of education and as a means of restoring the balance. Final report. Paderborn, Directorate-General for Education and Culture, Unit Sport.

Brodersen, N. H., Steptoe, A., Boniface, D. R., \& Wardle, J. (2007). Trends in physical activity and sedentary behaviour in adolescence: ethnic and socio-economic differences. British Journal of Sports Medicine, 41, 140-144. Retrieved from http://bjsm.bmj.com/ content/early/2006/12/18/bjsm.2006.031138.abstract.

Dalene, K. E., Anderssen, S. A., Andersen, L. B., Steene-Johannessen, J., Ekelund, U., Hansen, B. H., \& Kolle, E. (2018). Secular and longitudinal physical activity changes in population-based samples of children and adolescents. Scandinavian Journal of Medicine and Science in Sports, 28(1), 161-171. https://doi.org/10.1111/sms.12876.

Doak, C. M., Visscher, T. L. S., Renders, C. M., \& Seidell, J. C. (2006). The prevention of overweight and obesity in children and adolescents: a review of interventions and programmes. Obesity Reviews, 7(1), 111-136. https://doi.org/10.1111/j.1467789X.2006.00234.x.

Dobbins, M., Husson, H., DeCorby, K., \& LaRocca, R. L. (2013). School-based physical activity programs for promoting physical activity and fitness in children and adolescents aged 6 to 18. Cochrane Database of Systematic Reviews, (2). https://doi. org/10.1002/14651858.CD007651.pub2.

Dunton, G. F., Cousineau, M., \& Reynolds, K. D. (2010). The intersection of public policy and health behavior theory in the physical activity arena. Journal of Physical Activity and Health, 7(s1), S91-S98. https://doi.org/10.1123/jpah.7.s1.s91.

Farooq, M. A., Parkinson, K. N., Adamson, A. J., Pearce, M. S., Reilly, J. K., Hughes, A. R., ... Reilly, J. J. (2018). Timing of the decline in physical activity in childhood and adolescence: Gateshead Millennium Cohort Study. British Journal of Sports Medicine, 52(15), 1002-1006. https://doi.org/10.1136/bjsports-2016-096933.

Ferreira, I., Van Der Horst, K., Wendel-Vos, W., Kremers, S., Van Lenthe, F. J., \& Brug, J. (2007). Environmental correlates of physical activity in youth-a review and update. Obesity Reviews, 8(2), 129-154. https://doi.org/10.1111/j.1467-789X.2006.00264.x.

Fletcher, G. F., Balady, G., Blair, S. N., Blumenthal, J., Caspersen, C., Chaitman, B., ... \& Pollock, M. L. (1996). Statement on exercise: benefits and recommendations for physical activity programs for all Americans: a statement for health professionals by the 
Committee on Exercise and Cardiac Rehabilitation of the Council on Clinical Cardiology. Circulation, 94(4), 857-862. https://doi.org/10.1161/01.CIR.94.4.857.

Gunter, K. B., Almstedt, H. C., \& Janz, K. F. (2012). Physical activity in childhood may be the key to optimizing lifespan skeletal health. Exercise and sport sciences reviews, 40(1), 13-21. https://doi.org/10.1097/JES.0b013e318236e5ee.

Gustafson, S. L., \& Rhodes, R. E. (2006). Parental correlates of physical activity in children and early adolescents. Sports Medicine, 36(1), 79-97. https://doi.org/10.2165/00007256200636010-00006.

Hallal, P. C., Andersen, L. B., Bull, F. C., Guthold, R., Haskell, W., Ekelund, U., ... Wells, J. C. (2012). Global physical activity levels: Surveillance progress, pitfalls, and prospects. The Lancet, 380(9838), 247-257. https://doi.org/10.1016/S01406736(12)60646-1.

Janssen, I., \& LeBlanc, A. G. (2010). Systematic review of the health benefits of physical activity and fitness in school-aged children and youth. International Journal of Behavioral Nutrition and Physical Activity, 7(1), 40. https://doi.org/10.1186/1479-5868-7-40.

Kimm, S. Y. S., Glynn, N. W., Kriska, A. M., Barton, B. A., Kronsberg, S. S., Daniels, S. R., ... Liu, K. (2002). Decline in physical activity in black girls and white girls during adolescence. New England Journal of Medicine, 347(10), 709-715. https://doi. org/10.1056/NEJMoa003277.

Lima, R. A., Pfeiffer, K., Larsen, L. R., Bugge, A., Moller, N. C., Anderson, L. B., \& Stodden, D. F. (2017). Physical activity and motor competence present a positive reciprocal longitudinal relationship across childhood and early adolescence. Journal of Physical Activity and Health, 14(6), 440-447. https://doi.org/10.1123/jpah.2016-0473.

Marteau, T. M., Hollands, G. J., \& Fletcher, P. C. (2012). Changing human behavior to prevent disease: the importance of targeting automatic processes. Science, 337(6101), 1492-1495. https://doi.org/10.1126/science.1226918.

Matson-Koffman, D. M., Brownstein, J. N., Neiner, J. A., \& Greaney, M. L. (2005). A site-specific literature review of policy and environmental interventions that promote physical activity and nutrition for cardiovascular health: what works? American Journal of Health Promotion, 19(3), 167-193. https://doi.org/10.4278/0890-1171-19.3.167.

Mestna občina Ljubljana (2018). Strategija športa v Mestni občini Ljubljana [Strategic Plan for Sport in the City of Ljubljana until 2028]. Retrieved from https://www.sportljubljana.si/f/docs/Poslanstvo_in_vizija/Strategija-sporta-v-Mestni-obcini-Ljubljanado-2028-25.4.2018-za-jav.pdf.

Morton, K. L., Atkin, A. J., Corder, K., Suhrcke, M., \& Van Sluijs, E. M. F. (2016). The school environment and adolescent physical activity and sedentary behaviour: a mixedstudies systematic review. Obesity Reviews, 17(2), 142-158. https://doi.org/10.1111/ obr.12352.

Powell, K. E., \& Pratt, M. (1996). Physical activity and health. BMJ 313, 126-127. https:// doi.org/10.1136/bmj.313.7050.126.

Reilly, J. J. (2016). When does it all go wrong? Longitudinal studies of changes in moderate-to-vigorous-intensity physical activity across childhood and adolescence. Journal of Exercise Science and Fitness, 14(1), 1-6. https://doi.org/10.1016/j.jesf.2016.05.002.

Telama, R., Nupponen, H., \& Laakso, L. (2007). Determinants and correlates of physical activity among European children and adolescents. In W.-D. Brettschneider \& R. Naul (Eds.), Obesity in Europe: young people's physical activity and sedentary lifestyles (pp. 265-279). Berlin, Oxford: Peter Lang. 
Van Hecke, L., Loyen, A., Verloigne, M., van der Ploeq, H. P., Lakerveld, J., Brug, J., ... Deforche, B. (2016). Variation in population levels of physical activity in European children and adolescents according to cross-European studies: a systematic literature review within DEDIPAC. International Journal of Behavioral Nutrition and Physical Activity,13:70. https://doi.org/10.1186/s12966-016-0396-4.

Volmut, T., Pišot, R., \& Šimunič, B. (2013). Objectively measured physical activity in children aged from 5 to 8 years. Slovenian Journal of Public Health, 52(1), 9-18. https:// doi.org/10.2478/sjph-2013-0002.

World Health Organization (2010). Global recommendations on physical activity for health. Retrieved from http://whqlibdoc.who.int/publications/2010/9789241599979_eng. pdf. 